\title{
Statistical analysis of knowledge and awareness to universal basic education in Nigeria
}

\author{
Lukman Nafiu ${ }^{1}$, David Lanlege ${ }^{2}$, Danladi Hakimi ${ }^{1}$ \\ ${ }^{1}$ Department of Mathematics and Statistics, Federal University of Technology, Minna, Niger State, Nigeria \\ ${ }^{2}$ Department of Mathematics and Computer Science, Ibrahim Badamasi Babangida University, Lapai, Niger State, Nigeria
}

\section{Email address:}

firdaousmama@gmail.com(L. Nafiu)

\section{To cite this article:}

Lukman Nafiu, David Lanlege, Danladi Hakimi, Statistical Analysis of Knowledge and Awareness to Universal Basic Education in Nigeria. Science Journal of Education, Vol. 1, No. 3, 2013, pp. 28-35. doi: 10.11648/j.sjedu.20130103.11

\begin{abstract}
Nigerian educational system has gone through various developments and change. The main aim of this paper, which is knowledge and awareness of teachers to universal basic education in Nigeria is to investigate the perceived knowledge and awareness of teachers to universal basic education to aid proper implementation of the education policy through the proper involvement of the stake holders. The training and production of the manpower required for the attainment of Education policy objectives should be framed not only on the quality and quantity of teachers but also their involvement in policy formation. Analysis of the Nigerian education sector reveals the challenges of incoherence in policy formulation and implementation. One positive note is that both the government and the people are seeking better ways of doing things and achieving results that would benefit the majority of the people. Based on the findings, government is strictly advised to be proactive in the implementation of Universal Basic Education (UBE) for better monitoring strategy. It is also recommended that government needs to provide more in terms of library facilities, laboratory facilities and play materials for schools.
\end{abstract}

Keywords: Education, Basic, Knowledge, Awareness, Implementation and Teachers

\section{Introduction}

Education is referred to as a major force in economic intellectual, social and cultural empowerment [1]. It helps in the development of any country. Educational programs cannot be implemented without the teachers, for any country to be developed; the role of the teachers in education cannot be overemphasized. Teacher is one of the strong pillars of any society and country. Without good teachers, no country can progress. The importance of teachers in the life of a nation cannot be overlooked. The teacher influences the immature minds of-the youth. $\mathrm{He}$ treats and moulds the young mind into various forms. The future of a nation is built through the process of education. Any nation which tries to march ahead on the road to progress must do so with the help of able teachers. A nation cannot afford to leave its future in the hands of incompetent teachers.

It was stressed in [2] that the dependency of manpower training and development on teachers. He argued that teacher education should be basically related to every phase of development in Nigeria, for wherever one turns, be it economic, political or social spheres of activities, one is faced with the over-reoccurring problem of trained manpower needs but no adequate training can take place without competent teachers to handle the programme.

The origin and development of teacher education can be traced to the beginning of Western education in the country, the various church Missions such as the Wesley and Methodist, the Church Missionary Society, the Baptist, the Church of Scotland (Presbyterian) and the Roman Catholic were very active in Nigeria between 1842 and 1860 . They contributed in no small measure to the development of teacher education. According to [3], the missionaries devoted their attention initially to the development of elementary (primary) education in the country. This might be due to the little stipend the missions relied upon from their overseas headquarters.

When student, achieve poorly in academic works, everybody get concerned; parent, teachers, the institutions and students blame one another as being responsible. It is worthwhile to note that each of these has a part to play in effecting students' achievement. Every educational system in any known human society required highly skilled 
teaching personnel to sustain it. Hence, teachers are regarded as the most important elements in the school system. It is generally believed that no educational system could rise above the qualities of its teachers, Hence, the need for teachers to upgrade and update their knowledge and skills.

Nigeria got her independence from the British imperialist in October 1960. She however experienced a Civil war between 1968 and 1970 which had an adverse effect on her socio-economic development and consequently her educational system. The experiences of the civil war however rekindled Nigerians faith in education as government saw education as the major vehicle for national rehabilitation, reconstruction and reconciliation. The military unlike the civilian heavily depended on centralized administration. It launched the Universal Primary Education nationwide in 1976. The UPE gave rise to unprecedented growth not only in the primary but also at the secondary and tertiary levels. The demand for teacher education was enormous. The federal Government took over the financial responsibility for all Grade II teachers' Colleges in the Federation as part of the programme for the UPE scheme. In addition, the federal Government awarded bursaries to all pre-service teachers in the Colleges of Education and Universities. In addition the Federal Government founded more teacher training institutions with diversified programmed while universities were expanded [4].

In [5], it is opined that education has become a tool for the poor as the socially marginal red groups, an effective means of developing full capacities as potentials of human resources, and veritable means of developing a sound intelligent learning society. To attain the goals of a nation, the Nigeria Federal Ministry of Education (FME) under the Minister ship of Mrs. Obiageli Ezekwesili introduced a blue print for education reforms and intervention documented in the ministry's whole paper titled 'VISION 2020: The role of the Nigeria educational sector'.

The education reform embarked upon by government to stimulate national growth and development appears ambitious. It is aimed at providing education to all Nigerians irrespective of age, sex, religion, occupation, and location. The reform agenda according to [5], is leveraging a combination of strategic human and infrastructure capital reforms, aided by specific tactical intervention. The agenda includes the following:

(i) Operation Reach All Primary Schools (ORAPS) a condition assessment programme aimed at monitoring and assessing the state of all public primary schools with a view of meeting their needs. ORAPS is a follow up to ORASS (Operation Reach All Secondary Schools) successfully carried out over lest quarter of 2006. ORAPS is an exercise geared towards doing both qualitative and quantitative inspection of all primary schools in Nigeria.

(ii) Operation Reach All Secondary Schools (ORASS) also a condition assessment programme aimed at monitoring and assessing the state of all public secondary schools with a view of meeting their needs. ORASS was the first condition survey conducted by the ministry of education. Since the inception, 11,000 inspectors visited and inspected 14543 secondary schools.

(iii) Ready to Educate and Advanced and Develop (READ) which is geared towards encouraging a reading culture among youth.

(iv) Adopt-A-Public School initiative aims to leverage stakeholders in education particularly cooperate organizations, to come together as partners, for the purpose of rescuing public schools and consequently restored them to institutions capable of sound learning and attitudinal education.

(v) The Community Accountability and Transparency Initiative (CATI) seeks to get various institutions, civil society groups, town unions etc involved in holding UBEC, SUBEBS, Contractors and various ministries of education accountable for government disbursement at all tiers.

(vi) Innovation Enterprise Institution (IEI) is to advance Nigeria's economic growth through the maximization of human potential through excellence in vocational and technological training so as to develop the workforce and enhance Nigeria global competitiveness.

(vii) Universal Basic Education Reform aims at meeting century national and international imperatives.

(viii) The PPP initiatives will ensure the effectiveness of the federal Government Unity schools by bringing together various stakeholders in the education system to deliver innovative solutions to the problems of poor school management academic under achievement and poor utilization of public financial resources.

(ix) The consolidation initiatives will deliver the conversion of all Federal Polytechnics and Colleges of Education into campus of neighboring Federal Universities, thus improving the carrying capacity of the Universities, and satisfying the quest for university education and degree certification.

(x) The ed. TAP Initiative is to track the 'products' of Nigeria's educational system to determine who are their backgrounds, capabilities and need to inform a long term strategic planning process for the educational sector.

While acknowledging the need for education reform generally and for basic education in particular, there is need to carry along the teachers who are indispensable stakeholders. The teachers could be regards as the heart best of any education policy [6]. Teachers need to be consulted and involved in the formulation and implementation of any reform policy. They are professionals on whose shoulders the success or failure of any brand of education reform rests, the universal and 
compulsory nature of Universal Basic Education programme means mire teachers would be needed. They should be well trained and motivated. Teacher's that are unwilling to reach out to other stakeholders may not be desirable. Awareness and knowledge of teacher is basic to success of any education programme.

Available literature on reform has not addressed the basic school teacher's knowledge and awareness of in formulation and implementation of the education policy. Thus there is need to investigate the knowledge and awareness of teachers in Universal Basic Education with a view to suggesting relevant strategies for ensuring and enhancing the success of the reforms, especially at Basic education level. It is general belief that education plays a vital means in achieving development in all ramifications. In many countries, education has provided on dependable leverage for national development. In this regard, education and training have continued to be given a very high priority in countries national development plan in order to educate and prepare enough people to fill middle and high level positions in the private and public sectors of the economy. This is because the production of sufficient number of secondary and university graduates with the required skill, knowledge and expertise for filling the middle and high level position to prop the modern dynamic economics remain a challenge to educational planners ([7], [8], [9] and [10]).

For any nation to minimize illiteracy, ignorance and poverty as well as stimulate and accelerate the pace of national development, political consciousness and national integration, there is need to make basic education compulsory for the populace ([11] and [12]). Having recognized this fact, Nigeria introduces universal basic education about thirteen years ago. The study therefore investigates the perceived knowledge and awareness of teachers to universal basic education in national development.

\section{Purpose of the Study}

The study is set specifically to find out the

(i) Knowledge of teacher to universal basic education in Bosso local government area of Niger State.

(ii) Extent of teacher awareness to universal basic education in Bosso local government, Niger State.

(iii) Level of involvement of basic school teachers in the formulation and implementation of the universal basic education in Bosso local government in Niger state.

\section{Aim and Objectives of the Study}

The aim of this study is to investigate the perceived knowledge and awareness of teachers to universal basic education. Specifically, the objectives of this study are to find out if;

(i) teachers have knowledge of universal basic education Bosso Local Government Area, Niger State.

(ii) necessary infrastructures have been put in place for successful implementation of the programme.

(iii) teachers are aware of universal basic education

(iv) the functioning arrangement put in place is adequate or not

(v) there is necessary manpower for the successful execution of the scheme.

(vi) the programme has contributed to national development

\section{Research Questions}

In carrying out this study, the following research questions would be considered.

(i) Do teachers in Bosso Local Government Area, Niger State have knowledge of Universal Basic Education?

(ii) Are there necessary infrastructures in place for the successful implementation of the programme at Bosso Local Government Area, Niger State?

(iii) Are the teachers in Bosso Local Government Area, Niger State aware of universal basic education?

(iv) Is there qualified man-power for the successful execution of the programme at Bosso Local Government Area, Niger State?

(v) Is the funding arrangement put in place for the programme adequate?

(vi) Has the programme contributed to the social, economic and political development so far?

\section{Methods and Materials}

This study is a non-experimental type and a survey research design was adopted Questionnaires were sort out to teachers for response. The target population of the study comprises of all teaching staff in public and private primary schools in Bosso local government area of Niger State, Nigeria. The sample of the study was selected using the sample random sampling techniques. The technique was employed to select a total of one hundred teachers comprising male and female from the participating primary schools in the Bosso local government of Niger state. This was made up of eighty teachers from public school and twenty teachers from private schools respectively.

In order to collect data and provide answers to the research questions raised, the instrument employed in this study was questionnaire. A set of questionnaire was designed for the teachers in order to obtain information on their awareness on Universal Basic Education (UBE). This instrument is titled "questionnaire on knowledge and awareness of Teachers to Universal Basic Education (UBE) in Bosso Local Government Area of Niger State". The questionnaire was divided into seven sections. Section A of the questionnaire was designed to measure the 
demographics data of the respondents. Section B of the questionnaire was to provide information on the teachers' knowledge and awareness of the UBE. Section $C$ provides information about the comparison between UPE and UBE. Section D provides information on infrastructures. Section E provides information on the funding of the UBE. Section $F$ of the instrument provides information on the adequacy of manpower. While section $\mathrm{G}$ of the questionnaire provides information on the contribution of UBE to national development.

\section{Analysis and Results}

The package used for this study is Statistical Package for Social Sciences (SPSS) and the results obtained with are tabulated as follows.

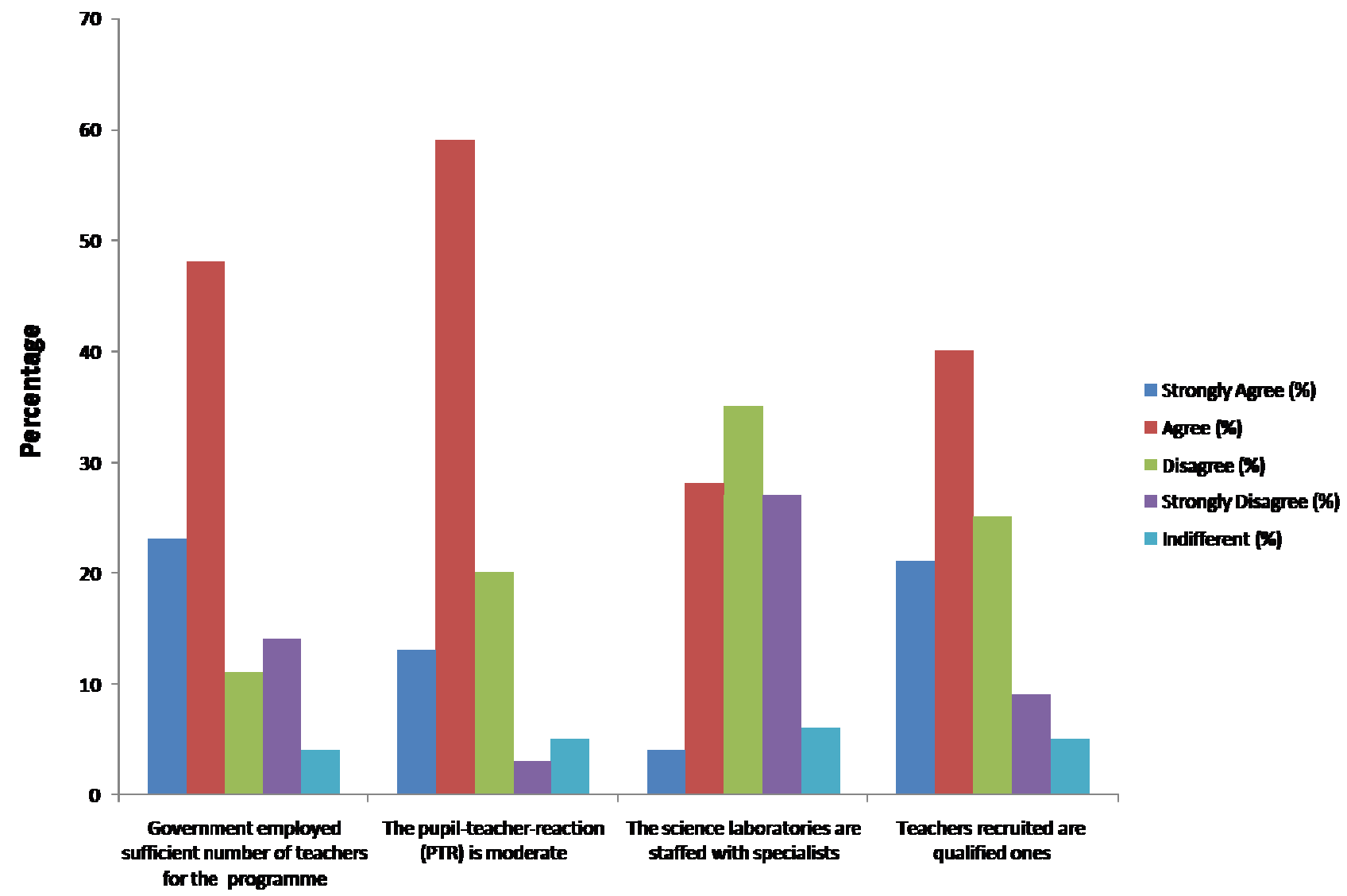

Table 1: Knowledge and Awareness

\begin{tabular}{|c|c|c|c|c|}
\hline & Yes $(\%)$ & No (\%) & $\begin{array}{c}\text { Nil } \\
(\%)\end{array}$ & TOTAL (\%) \\
\hline Are you aware of UBE? & 94.0 & 4.0 & 2.0 & 100.0 \\
\hline Do you have the knowledge of what UBE entails? & 89.0 & 8.0 & 3.0 & 100.0 \\
\hline Is your school enjoying fund from UBE scheme? & 48.0 & 49.0 & 3.0 & 100.0 \\
\hline Do you normally attend UBE meetings? & 33.0 & 64.0 & 3.0 & 100.0 \\
\hline Does your school participate in UBE decision making? & 51.0 & 45.0 & 4.0 & 100.0 \\
\hline Are you always allowed to make input to UBE? & 48.0 & 47.0 & 5.0 & 100.0 \\
\hline Does your school participate in the curriculum formulation? & 45.0 & 50.0 & 5.0 & 100.0 \\
\hline Are your pupils aware of UBE scheme? & 63.0 & 17.0 & 20.0 & 100.0 \\
\hline Is there any significant contribution of UBE to your school? & 59.0 & 21.0 & 20.0 & 100.0 \\
\hline Are you satisfied with the activities of UBE in your state? & 58.0 & 21.0 & 21.0 & 100.0 \\
\hline Is there any significant contribution of UBE to your pupils? & 48.0 & 32.0 & 20.0 & 100.0 \\
\hline
\end{tabular}

Table 1 gives a summary of an enquiry into whether the respondents have the knowledge and awareness of the Universal Basic Education (UBE). The table shows that about $94.0 \%$ of the respondents captured in the survey are aware of the UBE scheme leaving $4.0 \%$ of respondents that are unaware and $2.0 \%$ of respondents that feel indifferent. 
Similar responses were obtained for an enquiry into whether the respondents have the knowledge of what the UBE scheme entails. It was also observed that about the same percentage of the respondents in the survey are of the opinion that their schools are enjoying fund from the UBE scheme, leaving $3.0 \%$ of respondents that are indifferent. The table also reveals that the percentage of respondents that agree that they are given the opportunity to make an input to the UBE scheme is about the same as those that believe otherwise, leaving $5.0 \%$ of respondents that are indifferent. More importantly, the percentage (59.0\%) of respondents that agree that the UBE scheme has contributed significantly to their schools is higher than those that are of counter opinion with $21.0 \%$, leaving $20.0 \%$ of respondents that are indifferent. Finally, about $58.0 \%$ of the respondents in the survey believe that the UBE scheme has made significant impacts and contributions in their schools while $32.0 \%$ of the respondents believe otherwise, leaving $20.0 \%$ of respondents that are indifferent.

Table 2: Remarkable Departure from the Failed UPE

\begin{tabular}{|c|c|c|c|c|c|c|}
\hline & $\begin{array}{c}\text { Strongly } \\
\text { Agree (\%) }\end{array}$ & $\begin{array}{c}\text { Agree } \\
(\%)\end{array}$ & $\begin{array}{l}\text { Disagree } \\
(\%)\end{array}$ & $\begin{array}{c}\text { Strongly } \\
\text { Disagree }(\%)\end{array}$ & $\begin{array}{c}\text { Indifferent } \\
(\%)\end{array}$ & $\begin{array}{l}\text { Total } \\
(\%)\end{array}$ \\
\hline Present UBE covers much ground on basic than UPE & 30.0 & 47.0 & 13.0 & 1.0 & 9.0 & 100.0 \\
\hline The objectives of UBE are more detailed & 31.0 & 57.0 & 6.0 & 2.0 & 4.0 & 100.0 \\
\hline $\begin{array}{l}\text { UBE programme is not likely to face the constraint } \\
\text { witnessed by UPE }\end{array}$ & 13.0 & 39.0 & 33.0 & 9.0 & 6.0 & 100.0 \\
\hline $\begin{array}{l}\text { The present administration has facts and figures on projects } \\
\text { enrolment before commencement of the programme }\end{array}$ & 19.0 & 46.0 & 23.0 & 7.0 & 5.0 & 100.0 \\
\hline UBE success is guaranteed & 12.0 & 59.0 & 18.0 & 4.0 & 7.0 & 100.0 \\
\hline
\end{tabular}

Table 2 presents a summary of an enquiry into whether the respondents are of the opinions that there are some remarkable departures of the Universal Basic Education (UBE) from the failed Universal Primary Education (UPE) scheme. The table shows that the percentage of the respondents that agree that present UBE covers more ground on basic than UPE has the highest percentage of $47.0 \%$ followed by those that strongly agree that the scheme covers more ground the UPE, while those that are strongly disagree have the least percentage of $1.0 \%$. The table also reveals the responses of an enquiry into the contents of the UBE. The respondents that agree that the objectives of UBE are more detailed than those of the failed UPE have the highest percentage of $57.0 \%$ followed by those that strongly agree that the objectives of the UBE are more detailed with $31.0 \%$, whereas those that strongly disagree have the least percentage of $2.0 \%$. The table also shows the responses of an enquiry into whether the UBE programme is not likely to face the constraint witnessed by the erstwhile UPE. The respondents that agree that UBE programme is not likely to face the constraint witnessed by the erstwhile UPE have the highest percentage of $39.0 \%$ followed by those that disagree with $33.0 \%$, while those respondents that are indifferent have the least responses representing $6.0 \%$. The table also illustrates the responses gathered on whether the present administration has facts and figures on projects enrolment before commencement of the programme or not. The individuals that agree that the current government did so have the highest percentage of $46.0 \%$ followed by those respondents that strongly disagree with said facts and figures with $23.0 \%$, whilst those respondents that are indifferent have the least responses representing $5.0 \%$. The last but not the least, the table also gives the respondents' opinions on whether the success of the UBE is guaranteed or is a mere illusion. The respondents that agree that the success of the UBE programme is guaranteed have the highest percentage of $59.0 \%$ followed by those that disagree that the scheme may fail with $18.0 \%$, whereas those respondents that are indifferent have the least responses representing 7.0\%.

Table 3: Infrastructures for Successful Execution of UBE

\begin{tabular}{|c|c|c|c|c|c|c|}
\hline & $\begin{array}{c}\text { Strongly } \\
\text { Agreed (\%) }\end{array}$ & $\begin{array}{c}\text { Agree } \\
(\%)\end{array}$ & $\begin{array}{c}\text { Disagree } \\
(\%)\end{array}$ & $\begin{array}{c}\text { Strongly } \\
\text { Disagree (\%) }\end{array}$ & $\begin{array}{c}\text { Indifferent } \\
(\%)\end{array}$ & $\begin{array}{c}\text { Total } \\
(\%)\end{array}$ \\
\hline There is adequate furniture for the pupils & 22.0 & 30.0 & 28.0 & 16.0 & 4.0 & 100.0 \\
\hline There is adequate furniture for the teachers & 13.0 & 25.0 & 36.0 & 21.0 & 5.0 & 100.0 \\
\hline The libraries are equipped with library facilities & 7.0 & 21.0 & 31.0 & 36.0 & 5.0 & 100.0 \\
\hline There is provision for functional science laboratories & 3.0 & 21.0 & 31.0 & 39.0 & 6.0 & 100.0 \\
\hline The classrooms are in commensurate with the enrolment & 11.0 & 36.0 & 28.0 & 21.0 & 4.0 & 100.0 \\
\hline
\end{tabular}


Table 3 gives a summary of the opinions of the respondents on the state of the infrastructural facilities for successful completion of the UBE programme. The respondents that agree that there is adequate furniture for the pupils have the highest percentage of $30.0 \%$ and this is followed by those that disagree with $28.0 \%$. The respondents that are indifferent to the state of infrastructures have the least percentage of $4.0 \%$. The table also shows respondents' opinions on whether there is adequate furniture for the teachers in Niger State primary schools or not. The respondents that disagree that there is adequate furniture for the teachers have the highest percentage of $36.0 \%$ followed by those that agree for such furniture provision with $25.0 \%$, whereas the respondents that are indifferent have the least percentage of $5.0 \%$. In addition, the table also reveals a summary of an enquiry into whether the libraries in Niger State primary schools are equipped with library facilities or not. The respondents that strongly disagree that the libraries in Niger State primary schools are equipped with library facilities have the highest percentage of $36.0 \%$ followed by those that disagree with respect to such

Library facilities provision with $31.0 \%$. The percentage of respondents that strongly agree and those that are indifferent with respect to the libraries in Niger State primary schools being equipped with library facilities are about the same with $7.0 \%$ and $5.0 \%$ respectively. The table also affirms the respondents' opinions on whether there is provision for functional science laboratories in Niger State primary schools are about the same for responses for that of library facilities provision discussed above, except that the percentage of respondents that strongly agree and those that are indifferent with respect to functional science laboratories provision have $3.0 \%$ and $6.0 \%$ respectively. Besides, the responses of an assessment of whether the available classrooms are in commensurate with the pupils' enrolment in Niger State primary schools was summarised in Table 4.3. The proportion of the respondents that agree that classrooms are commensurable with pupils' enrolment has the highest percentage of $36.0 \%$ followed by those that disagree with $28.0 \%$, while $4.0 \%$ of the respondents remains indifferent.

Table 4: Funding Adequacy

\begin{tabular}{|c|c|c|c|c|c|c|}
\hline & $\begin{array}{c}\text { Strongly } \\
\text { Agree (\%) }\end{array}$ & $\begin{array}{c}\text { Agree } \\
(\%)\end{array}$ & $\begin{array}{l}\text { Disagree } \\
(\%)\end{array}$ & $\begin{array}{c}\text { Strongly } \\
\text { Disagree (\%) }\end{array}$ & $\begin{array}{c}\text { Indifferent } \\
(\%)\end{array}$ & Total (\%) \\
\hline Government votes adequate fund to UBE programme & 21.0 & 56.0 & 14.0 & 4.0 & 5.0 & 100.0 \\
\hline $\begin{array}{l}\text { The fund vote meant for UBE is released as at when } \\
\text { due }\end{array}$ & 8.0 & 39.0 & 37.0 & 9.0 & 7.0 & 100.0 \\
\hline Government is sincere with UBE financial policy & 12.0 & 50.0 & 28.0 & 4.0 & 6.0 & 100.0 \\
\hline There is transparent in the disbursement of UBE fund & 9.0 & 36.0 & 35.0 & 13.0 & 7.0 & 100.0 \\
\hline $\begin{array}{l}\text { The school is not short of fund in executing some } \\
\text { project }\end{array}$ & 12.0 & 28.0 & 36.0 & 20.0 & 4.0 & 100.0 \\
\hline
\end{tabular}

Table 4 presents a summary of issues relating to funding adequacy for full implementation of the UBE programme. The table points out that respondents that agree that government allocates adequate fund to UBE programme have the highest percentage of $56.0 \%$ followed by those that strongly agree, while the respondents that strongly disagree that government allocates adequate fund to UBE programme have the least percentage of $4.0 \%$. The table also shows the opinions of the respondents on timely release of the allocated fund for the UBE programme. The respondents that agree that government releases fund to UBE programme as at when due have the highest percentage of $39.0 \%$ followed by those that disagree with $37.0 \%$. The respondents that strongly agree and strongly disagree that government releases fund to UBE programme as at when due have about the same percentage of $8.0 \%$ and $9.0 \%$ respectively, while the respondents that are indifferent have the lowest percentage of $7.0 \%$. It is also observed from the table that the respondents that agree that there is sincerity on the part of government with respect to UBE financial policy have the highest percentage of $50.0 \%$ followed by those that disagree, whereas the respondents that strongly disagree with this have the least percentage of $4.0 \%$. Similarly, the respondents that agree and disagree that there is a transparency in the disbursement of UBE fund on the part of government and relevant stakeholders have about the same percentage of $36.0 \%$ and $35.0 \%$ respectively, while the respondents which are indifferent have the lowest percentage of $7.0 \%$. The last but not the least, the table shows the respondents' opinions on whether the Niger State primary schools are not short of fund in executing some project or not. The respondents that disagree that the schools are not short of fund in executing some projects have the highest percentage of $36.0 \%$ followed by those agree with $28.0 \%$, while the respondents that are indifferent have the lowest percentage of $4.0 \%$. 
Table 5: Manpower Adequacy for full Implementation of the UBE Scheme

\begin{tabular}{|c|c|c|c|c|c|c|}
\hline & $\begin{array}{c}\text { Strongly } \\
\text { Agree (\%) }\end{array}$ & Agree (\%) & $\begin{array}{l}\text { Disagree } \\
(\%)\end{array}$ & $\begin{array}{c}\text { Strongly } \\
\text { Disagree } \\
(\%)\end{array}$ & $\begin{array}{c}\text { Indifferent } \\
(\%)\end{array}$ & Total (\%) \\
\hline $\begin{array}{l}\text { Government employed sufficient number of teachers } \\
\text { for the programme }\end{array}$ & 23.0 & 48.0 & 11.0 & 14.0 & 4.0 & 100.0 \\
\hline The pupil-teacher-reaction (PTR) is moderate & 13.0 & 59.0 & 20.0 & 3.0 & 5.0 & 100.0 \\
\hline The science laboratories are staffed with specialists & 4.0 & 28.0 & 35.0 & 27.0 & 6.0 & 100.0 \\
\hline Teachers recruited are qualified ones & 21.0 & 40.0 & 25.0 & 9.0 & 5.0 & 100.0 \\
\hline
\end{tabular}

Table 5 presents a summary of the state of manpower adequacy for full implementation of the UBE programme in Niger State primary schools. The respondents that are of the opinions (agree) that government employed sufficient number of teachers for the programme have the highest percentage of $48.0 \%$ followed by those that strongly agree on the common ground with $23.0 \%$, whereas the respondents which are indifferent have the lowest percentage of $4.0 \%$. It is also evident from the table that the respondents that agree that the pupil-teacher-reaction (PTR) is moderate in Niger State primary schools have the highest percentage of $59.0 \%$ followed by those that disagree with $20.0 \%$. The respondents that strongly disagree and those that are indifferent on the position that the pupil-teacherreaction (PTR) is moderate in primary schools under the survey represent $3.0 \%$ and $5.0 \%$ respectively. Respondents that disagree that the science laboratories are staffed with specialists have the highest percentage of $35.0 \%$. The respondents that agree and those that strongly disagree have about the same response count representing $28.0 \%$ and $27.0 \%$ respectively, while those that strongly agree have the least percentage of $4.0 \%$. The last but not the least, the table shows that the individuals in the survey that agree that qualified teachers are employed for the UBE scheme have the highest percentage of $40.0 \%$ followed by those that disagree with $25.0 \%$, whereas those respondents that remain indifferent have the least response count representing $5.0 \%$.

\section{Discussion of Results}

This study found that the teachers in Niger State primary schools have a significant knowledge of the UBE scheme as can be seen in Table 1, where about $89.0 \%$ of the respondents claimed to have knowledge of the scheme. This is probably due to the activities of the Federal Government through its Ministry of Education to reach out to virtually all primary schools in the state in particular, and Nigeria in general; in terms of erection of classrooms for schools and provision of writing materials for pupils. Besides, the high figure observed in this study might also be attributed to the efforts of the federal government in rewarding the states of the federation that contributed best in terms of funding the UBE scheme. For instance, for the 2010 award, Rivers State was adjudged the best performing state; Adamawa came second, while Kebbi State came third in the national contest.

It was also found that the infrastructures are provided but not adequate at present as can be seen in Table 2. This finding reveals the extent to which the Federal Ministry of Education in 1999 proposed implementation of blueprint have been carried out. It was planned in the blueprint that, additional 1.12 million pupils are to be recommended and then, additional facilities such as classrooms $(28,000)$, more teachers $(28,000)$ and other materials are to be provided. It has been revealed that there is adequate furniture for the pupils from whom it could be inferred that there are enough classrooms, teachers also have enough furniture but facilities such as libraries, laboratories have not been adequately provided. This also could be as a result of leakages in the fund budgeted for the implementation of the programme.

The study also found that there is enough man-power necessary for the successful implementation of the programme as can be seen in Table 3 . This finding reveals how far the government had recruited teachers as proposed in the implementation blueprint FME in 1999. It was planned that about 28,000 teachers would be recruited so as to have approximately 1:40 teacher - pupil ratio. It was noticed as of recent that large number of teachers were employed for the UBE programme in almost all the states of the federation. No wonder the respondents who were teachers agreed that government employed sufficient teachers for the programme. They also confirmed that the few libraries that were put in place were staffed with specialists, and so also the science laboratories. It was also confirmed that qualified teachers were recruited unlike in the case of the UPE when both qualified and unqualified teachers were recruited to teach in the schools.

Finally, it was found that though government sincerely devoted adequate fund for the programme but there is no transparency in the disbursement of the UBE fund as can be seen in Table 4. This finding supported previous discussion. The government was aware of what it will cost to put UBE programme in the right shape and was ready to pay the price, but it is sad that the channel by which the money would pass through to the people that would implement the programme is full of fraud. The money that gets to the schools is so small that most of the facilities planned for could not be supplied again. UBE has contributed immensely to social harmony, people's political awareness, and improved productive capacities and has promoted religious tolerance. This study is in line with the aims of the 
programme as stated by the FME in 1999. The aim among others is to equip the recipients with the knowledge, skills and attitudes that will enable them to live meaningful and fulfilling lives, derive maximum social, economic and cultural benefits from the society and so on as can be seen in Table 5. This could be as a result of the fact that the scope, objectives and method of implementation of UBE make the programme more functional than any of its kind that has been practiced before. The programme has all that it takes to be more successful.

\section{Conclusion and Recommendations}

Based on the findings of this study, the following recommendations are proffered, for better implementation and to make the UBE programme more effective: Since Nigeria is now getting rooted in democratic system of government, the next people in government are strictly advised not to change or stop the implementation of UBE because it has been found to be far better and more promising than the previous programmes.

However, monitoring of the implementation strategies need to be put in place to ensure maximum results. Chairs, tables, classrooms provided for this programme in the state (Niger State) and other parts of country are almost enough, except in some rural areas. There is a need for government to provide more in terms of library facilities, laboratory facilities and play materials. In fact, from schools visited during the study it seems play materials are inexistent in the primary schools and knowing fully that the best method of teaching the pupils at this level is through play most especially the pre-primary level. Adequate provision should therefore be made for play materials, library facilities and laboratory facilities in order to give the pupils chances to explore their environment through their interaction with such materials.

It is also very important that a better monitoring strategy be designed for the fund released to the programme so as to ensure proper usage of such funds. It should be noted that a well-planned programme, that is well funded might be rendered ineffective through embezzlement and corruption. If all these are ensured, then, UBE programme still have more in stock to give to Nigerians in terms of national development as found in some other countries such as the United States, Tanzania and so on.

Amongst the findings of the study are the remarkable departure of UBE from the failed UPE; provision of infrastructures though not adequate (e.g. libraries and laboratories), release of adequate fund but with no transparency in the disbursement, and adequate provision of necessary manpower for the successful implementation of the programme and finally, enhanced social, economic and political development in the nation due to the introduction of UBE. Based on the findings, it is recommended that, Nigerian government should be more conscious of the monitoring of UBE implementation and thus pay more attention to this area so as to ensure maximum result. More furniture should be provided to schools in the interior parts of the country.

\section{References}

[1] B. Burtch, Education Law and Social Justice: Widening Access to Education as Social Justice, Netherlands: Springer, 2006, pp. 83-94.

[2] E.O. Adu, Universal Basic Education Towards a Functional Development of Nigeria Educational System Management of Primary and Secondary Education in Nigeria. Nigeria: NAEAP Publication, 2004, pp. 439-4446.

[3] S.D. Akangbou, The Economics of Educational Planning in Nigeria, New Delhi: Vikas Publishing Limited, 1985.

[4] M. Fabunmi, A. Akinwumiju, and C.N. Uyanwa, "Planning Universal Basic Education for National Development", Department of Teacher Education, University of Ibadan, Nigeria, 2002.

[5] Federal Ministry of Education, Country Report. Abuja: FME, 1996.

[6] A. Yusuf, Teacher's Opinion of Incorporating Environmental Education EE in the Primary School Curriculum.www. edujornal.org, 2006.

[7] IFESH, "Teacher for Africa Program". International Consultative Forum on Education for all (EFA Forum), 2001.

[8] I.A. Raji, Provision of Basic Education in a Federal State: A Search for an Efficient Education in Nigeria, Nigeria: NAEAP Publication, 2004, pp. 427-438.

[9] A. Tostensen and J.G. Scott, Kenye: Country Study and Norwegian Aid Review, Bergen, Norway: The Chr. Michelsen Institute, 1987.

[10] UNDP, Nigeria Human Development Report. Lagos, Nigeria: UNDP, 1998.

[11] V. W. Dike, "School Library Facilities Required for Successful Implementation of the Universal Basic Education in Nigeria". Paper Presented at the 16th Annual Conference of the Nigeria School Library Association, at the Children's Centre library, UNN, 23-26 October, 2000, pp. 2-7.

[12] E.F. Denison, The Source of Economic Growth in the United State and the Alternative before. New York: Committee for Economic, 1962. 